\title{
Determinants of Performance in the Wood Industry in Ghana: An Overview
}

\author{
Fidelis Quansah \\ University of Professional Studies, Accra \\ Patrick Tandoh-Offin \\ School of Public Service and Governance, GIMPA, Accra
}

Received: June 2, 2016 Accepted: June 21, 2016

doi:10.5296/ber.v7i2.9542 URL: https://doi.org/10.5296/ber.v7i2.9542

\begin{abstract}
The potential that the wood industry presents for diversifying national economies through improved foreign exchange earnings, increased employment opportunities, and local economic development cannot be underestimated. At the global level, this potential of the wood industry has been deemed to be dependent on factors such as market orientation, firm size, management attitudes, and firm, industry, product and market characteristics. Thus, it is possible for countries and economies at different stages of development, different levels of industrialization and with differing levels of wood or forestry resource endowment to demonstrate or respond differently to the industry's potential benefits also at the local or domestic level. The wood industry in Ghana contributes significantly in all three areas mentioned above. It also contributes about $4 \%$ of the national tax revenue in Ghana. It is clear therefore that the performance of the wood industry depends on the above-mentioned factors. This study aims to determine which factors are the most important for evaluating the performance in Ghana's wood industry, especially in a global market space where being internationally competitive is essential. The study reviews empirical research that have applied factors that have generally been accepted by researchers to be the determinants of performance in the wood industry as a way to assess the usefulness of such factors in evaluating and making appropriate recommendations for improving performance in the wood industry in Ghana.
\end{abstract}

Keywords: Extractive resources, Wood export performance, Economic development

\section{Introduction}

The wood industry grants a potential for differentiating national economies through better 
foreign exchange earnings, improved employment opportunities, and local economic development cannot be undervalued. This potential of the industry at global levels is deemed to be dependent on market orientation, firm size, management attitudes, and firm, industry, product and market characteristics. Hence possibility of different countries at different stages of development responding differently to the industry's potential benefits also at the local or domestic level. The wood industry in Ghana contributes significantly to the economy in terms of foreign exchange earnings, increased employment and opportunities for local development. The industry is dominated mainly by private SMEs that averagely accounts for about $6 \%$ of GDP. The sector is the fourth most important foreign exchange earner accounting for $11 \%$ of GDP after Minerals (36\%), Cocoa (35\%), and Tourism (12\%). It provides direct employment to more than 100,000 people in logging and processing mills as well as in public institutions. It also contributes about $4 \%$ of the national tax revenue in Ghana. It is clear therefore that the performance of the wood industry depends on the above-mentioned factors. But the Ghana Statistical Service's provisional GDP estimates and sector performance report (2011), has indicated that Forestry and Logging declined by 14 per cent from the 2010 figures.

This study aims to determine which factors are the most important for evaluating the performance in Ghana's wood industry, especially in a global market space where being internationally competitive is essential. Main question of the study therefore was what are the internal firm characteristics that affect the performance of the wood industry in Ghana? In this exploratory study, we review empirical research that has applied factors generally accepted by researchers to be the determinants of performance in the wood industry to assess the situation for the performance of Ghana's wood industry. The goal is to assess the usefulness of such factors in evaluating and making appropriate recommendations for improving performance in the wood industry in Ghana. The study serves as a useful tool for academia in the case of further research on the contributions of the wood sector to Ghana's Economic Development. Research further provides insight into the extent to which key determinants affect export performance in the wood industry and which determinants are important to improving performance of the wood industry. In the sections that follow, we attempt to trace the determinants of export performance through a review of relevant literature and theoretical positions on the timber or wood industry.

\section{Export Performance in the Wood Industry}

Research on export performance in the wood industry has discovered several influencing variables, but the type and magnitude of the impacts have not been determined (Chetty and Hamilton, 1993). Katsikeas, Leonidou and Morgan (2000) explain that because none of the existing export performance measures have attained universal acceptance, it gets more complex when assessing the impact of a given factor through a specific measure. This could be because of mediating and/or moderating interactions that could exist. Aaby and Slater (1989) grouped variables used to explain export performance into four sets. The first group consists of firm characteristics (size, managerial commitment, and managerial perceptions). Secondly, firm competences (technology, market knowledge, market planning, export policy, control systems, quality control, and communication skills). Thirdly, export strategy which include market selection, use of intermediates, product mix, product development, promotion, 
and pricing, and finally, external environment.

Accordingly, Katsikeas, Leonidou and Morgan (2000) on the other hand, considered them either internal (export strategy, managers' perceptions and attitudes, managers' characteristics, and firm's characteristics and competences), or external (industry characteristics, external and domestic market characteristics) determinants of export performance. Furthermore, Moini (1995) suggested three broad classes: organizational characteristics (size, international experience, competitive advantages, etc.); managers' expectations (both positive and negative); and managers' characteristics (age, formal education, experience, knowledge of foreign languages); while adding a fourth factor, systematic search for new external markets. Katsikeas, Leonidou and Morgan (2000) review led to two sets of factors - target market selection and export strategy - with direct effect on export performance and three sets of factors - managers' characteristics, organizational characteristics and environmental variables - indirectly influencing export performance. Leonidou, Katsikeas and Samiee (2002) found that the impact on export performance varied according to the specific facet or measure of export performance selected, and that five types of variables seemed to dominate most of the studies: managers' characteristics, organizational factors, environmental forces, export target, and export marketing strategy.

\section{Determinants of Success in Export Performance}

The factors that drive export success, such as marketing (or market) orientation, firm size, management attitudes, and firm, industry, product and market characteristics have been extensively reviewed and categorised (Cavusgil and Zou, 1994; Chetty and Hamilton, 1993; Dau, 1992; Diamantopoulos and Cadogan, 1996; Madsen, 1989; McGuinness and Little, 1981; Slater and Narver, 1996 always be chronologically consistent with the citations oldest first or earliest first). These studies have conceptualised models of export behavior e.g. Aaby and Slater, 1989; and Cavusgil and Zou, 1994, focused on perceived barriers to engaging in export activity, either across firms at different stages of internationalization e.g. Ford and Leonidou, 1991, or among firms at the same stage of export involvement e.g. Barrett and Wilkinson, 1985 and Burton and Schlegelmilch, 1987. However, Katsikeas et al, 1996 infer that a systematic review of the pertinent empirical literature suggests that the vast majority of the research efforts have surveyed firms connected with exporting from highly industrialized countries. An implication of this is that it may be both dangerous and potentially misleading to deduce generalizations from such findings to export performance in other countries, especially those at a different stage of development and/or with a different domestic market size like Ghana. To this end, a review of the relevant literature and theoretical positions on the subject is necessary to carve out a path for Ghana's burgeoning wood industry.

Numerous researchers have identified both internal and external factors which influence export performance: Aaby and Slater (1989), Cavusgil and Zou (1994), Leonidou and Katsikeas (1996), Katsikeas et al. (2000), Leonidou et al. (2002) and Sousa (2004). Internal factors typically include the product, and managerial and organizational characteristics such as planning abilities, technology, and firm size. External factors, on the other hand, involve both domestic and target market characteristics. Export performance is "a composite 
outcome of a firm's international sales, which includes three dimensions: export sales, export profitability and export growth" (Shoham, 1998). It highlights multi-dimensionality of construct but remains quite broad, and represents variables which will indicate whether the export activity is more or less successful (Maurel, 2009). This implies that in measuring export performance of a firm, one cannot use a single indicator such as sales volume or value. Both subjective and objective constructs which influence export performance have also been identified. Subjective constructs are the export marketing mix, information sources, entrepreneurial orientation, export stimulus, export problems, and trade barriers. Objective constructs are the firm size, the export to total sales ratio, and export experience. Indirect influences on export performance through the export marketing mix are management, export competencies, export market attractiveness, and the similarity of export and domestic markets.

\section{Empirical Studies on Selected Determinants: Theoretical Relationships}

Wood and wood products are increasingly traded regionally and globally and the volume and direction of investments in production and processing are changing depending on how the products could be produced competitively, both in the short and long term (Sasatani, 2009). Therefore theoretically, Ghana, a country endowed with forest reserves stands a better chance of succeeding in the wood trade. However, there are many intervening variables such as the extent to which trade policies are formulated to support wood exporting firms to take advantage of the abundance of raw materials to compete in the global market. Notwithstanding, Ajayi (2005) noted that for policy makers, the perception of benefit that will accrue by way of foreign exchange is the overriding factor in putting in place an export promotion programme. Government Export Assistance Government Export Promotion Programmes (EPPs) normally define the premise for successful exporting activities of the corporate sector and play a key role in stimulating the international business activities of firms (Wood and Berge, 1997), but a systematic examination of their causal relation with Firm Export Promotion (FEP) is scarce. An extensive search of the literature reveals that most mainstream studies on export performance are narrowly focused on firm-related determinants and only a hand-full of studies have explored the impact of EPPs on FEP (Wood and Owens, 1997).

Research appears to indicate that the existence of programs sponsored by government and nongovernment agencies designed to assist firms' export activities contribute positively to the export performance of the firm (Alvarez 2004; Wood and Berge, 1997). The basic objective of these programs is to act as an external resource from which firms gain knowledge and experience. With these extra resources, firms might create or develop existing international networks as well as develop plans to build upon a much more sophisticated analysis of the foreign environment, both of which are vital for successful foreign market involvement. This relationship explains why some literature on the export assistance topic suggests that there is a strong need to develop models that incorporate intervening and indirect influences among export assistance and export performance (Alvarez 2004). In particular, some studies on the topic (Wood and Berge, 1997) suggest that there is an increasing need to develop more policy-oriented international business research that analyzes the interface between export 
assistance and performance. These studies suggest that if public policy-makers provide export assistance to firms willing to adapt pricing strategies, export assistance will be well allocated because pricing strategy adaptation will lead to a better performance (Sasatani, 2009) It can be inferred that EPPs alone may not lead to improved performance if the firm does not adapt their strategies to take full advantage of the assistance. Thus, in exploring the subject of export assistance in the Ghanaian wood industry, this study will also explore the extent of adaption among wood-exporting firms to create a competitive advantage in the global market.

The Influence of Monetary Policy Policy-makers has always been attentive to the effects of exchange rate misalignments, not the least because the International Monetary Fund (IMF) precludes competitive devaluations which create unfair trade advantages (World Bank, 1997). From a macroeconomic point of view, exchange rateshifts affect international trade both in direct and indirect ways (Ajayi, 2005). The indirect links are hard to isolate macro-economically, complex to describe, and empirically hard to test, as they have second, third or fourth round effects. This is why exchange rates are often treated in models as external (exogenous) variables (Sasatani, 2009). Exchange rates can in principle influence trade in many ways. Real exchange rates, which are the relative prices of tradable to non-tradable products, are also a measure of real competitiveness, as they capture the relative prices, costs, and productivity of one particular country vis-à-vis the rest of the world (Ajayi, 2005). Therefore, volatility in the exchange rate regime can affect a firm's decision to export through an evaluation of its competitiveness in foreign markets, cost of production and relative prices (Sasatani, 2009).

In the early (1970s and 1980s), theoretical analyses and models of the relationship between exchange rates and international trade focused primarily on the commercial risk involved in conducting international transactions and the uncertainty generated by short-term or longer-term volatility. The models focused on how this uncertainty affected the decision to trade, its expected profitability, and eventually the allocation of resources. Thus, the view that an increase in exchange rate volatility will have adverse effects on the volume of international trade is relatively widespread in studies conducted throughout the 1970s and 1980s inter alia, Wood and Berge (1997) and others, at a period of increased volatility (World Bank, 1997).

Reflecting the relatively inconclusive state of early theoretical models regarding the effects of exchange rate variability on trade, the vast empirical work conducted by academics and policy oriented economists in support of theoretical considerations fails to provide clarification (Ajayi, 2005). This is reflected by the industrial and contingency theories since the impact of exchange rate volatility on export performance will vary from industry to industry and from firm to firm. One simple but relatively well known example of how exchange rates affect trading firms is provided in a seminal paper by Sasatani (2009), who describes the hypothetical case of a firm, producing under perfectly competitive conditions, a single product containing no imported input, entirely for export markets. The firm is paid only in foreign currency; hence, the proceeds of its exports in domestic currency depend on the (unpredictable) level of the exchange rate. Thus, the firm in question must determine a level of export that incorporates this uncertainty. In other words, this basic model, later 
refined by Hooper and Alvarez (2004), establishes a rather negative relationship between exchange rate volatility and international trade.

In several other models, the effect of increased volatility of exchange rates on trade depends heavily on the level of risk aversion of traders (Alvarez 2004; Cavusgil and Zou, 1994; Chetty and Hamilton, 1993). Risk-neutral traders are unlikely to be affected by exchange rate uncertainty but risk adverse ones will, albeit in different degrees. Paradoxically, for very risk-adverse traders, exporting more could be a response to increased volatility, in order to compensate for the expected fall in revenue per exported unit. As indicated by Sasatani (2009), while "exporters are universally made unhappy by the volatility of exchange rates, some may decide that they will be better off exporting more". In this particular case, he stresses that the dominance of income effects over substitution effects results in a positive relationship between exchange rate fluctuations and the volume of trade.

Firms that were able to react flexibly to changes in the exchange rate and re-allocation of their products had a positive effect on the exchange rate volatility (Alvarez, 2004). Thus through this the firm is able to maximize their gains from the trade or exchange. As indicated by the authors, "the export strategy is like an option because the domestic market is certain whatever the realized exchange rate turns out to be (Alvarez, 2004). The domestic price is the "strike" price of the real export option. However, a more volatile exchange rate also implies a higher risk of exposure for international firms (Wilkinson and Brouthers, 2006). The authors conclude that the net effect of exchange rate uncertainty on production and exports in their model would depend on the degree of relative risk aversion of the firm. The performance of the wood industry is also dependent on the monetary policies that have been put in place. A more volatile exchange rate will affect the economic conditions of the business which will eventually impact on its performance in the marketing environment.

\subsection{Use of Technology: Insights from Market Imperfections Theory and Technology}

In the conception of this study, innovation will not be viewed as a standalone variable; its relationship with intervening variables will be assessed. Furthermore, the role of innovation in the wine industry, for example, is confirmed by Remaud (2006) on New Zealand and French small wine companies. It is also supported by Woods and Kaplan (2005) dealing with the role of innovation in the ability of South African wine firms to face competition when re-entering international markets. It is this positive role of innovation on export performance which will be tested in this study of the wood industry in Ghana. International marketing requires current updated technology and innovative products to remain sustainable. According to Aaby and Slater (1989), technology is known to be one of the most important factors for a firm to maintain its competencies as it stands for strategies leading to performance. Besides, technical innovations reflect the technology gap theory of trade originally suggested by Krugman (1994). Both these theories assign a crucial role of technological innovation in the structure of trade. Technology-based models of export performance focus on firms' investments or achievement in implementing new technologies or the development of new products or processes. This capability will depend both on the internal strengths of the firm, including where applicable its links to other group companies 
and on the support available from the regional or national innovation system within which the firm is operating (Aaby and Slater, 1989). Also, the presence of a research and development $(R \& D)$ function within a firm, for example, may stimulate innovation through the type of technology push process envisaged in linear models of innovation. In this regard, this study will assess the level of investment in technology in the Ghanaian wood industry as well as the extent of innovation in both products and processes. The impact of these factors on firm export performance will then be analyzed with both practical and theoretical perspectives.

\subsection{Skilled Labour}

Insights from the Resource-Based View Management is part of the internal environment and includes the ability to use appropriate technology, establish and nurture committed personnel, acquire knowledge, set export aims, and establish management control systems. The ability to analyze and plan is a discriminator between successful exporters and non-exporters (Aaby and Slater, 1989; Christensen et al., 1987) and poor management causes weak performance (Wood and Owens, 1997). Managerial Competence Exporting is a dynamic process and managers need to monitor environmental changes and be proactive and flexible in making strategy (Aaby and Slater, 1989). Export success is linked to effective control and monitoring of performance, decentralized decision making, and education and training (Christensen et al. 1987). Thus, the literature suggests that management characteristics may significantly influence a firm's export success. As such, the variations in export activity can be explained, to a significant extent, by management characteristics (Katsikeas, Leonidou and Morgan (2000). Aaby and Slater (1989) caution researchers not to undervalue the link between managers' attitudes towards exporting and firm export performance. Indeed, she finds managers' perceptions of the relative advantage of exporting to be the most significant indicator of firm export performance. This is consistent with the view that commitment at the top management level is crucial for the export success of the firm (Cavusgil 1984; Cunningham and Spiegel 1971; Evangelista 1994). The rationale for this view is that, when managers are committed, they carefully plan the entry and allocate sufficient managerial and financial resources (Christensen et al. 1987). As a result, uncertainty is reduced and marketing strategy can be implemented effectively (Aaby and Slater 1989), leading to better performance (Cavusgil and Zou 1994).

Other variables included in this category as determinants of export performance were educational background and innovative and professional experience. Previous research in this area reports that better-educated managers with a good command of foreign languages and extensive professional experience are more successful in exporting (Cavusgil and Zou 1994; Christensen et al. 1987). In this review, however, mixed results were obtained for the impact of the manager's international experience on the export performance of the firm. While Alvarez (2004) found a positive relationship between managers' international experience and export performance, Wood and Berge (1997) found no support for the hypothesis that managers with greater international business experience will have stronger export performance in their companies. The positive relationship reported by Ajayi (2003) is probably due to the fact that managers with greater experience in international business have a better understanding of foreign markets, which may help a firm to identify opportunities 
while avoiding threats in international markets. The findings of Alvarez (2005), however, could be explained by the characteristics of the industry used in their study. They argue that, in the software industry, managers do not have to possess significant international experience, as they can reach out to foreign buyers through a combination of Internet and formal/informal networks.

Non-Managerial Personnel Export personnel are one of the crucial competitive advantages for companies since they have such expertise and skills as understanding foreign customers, effecting systematic marketing planning, exploring and analyzing marketing opportunities, and handling exporting procedures (Cavusgil and Zou 1994). Studies by Christensen et al. (1987) identified that the lack of qualified export personnel undermines company export performance. Majority of the literature reviewed have focused on top level management as a determinant of export performance, however, this study will assess a composite of top-level management as well as other personnel and its impact on export performance.

\subsection{Knowledge of Export Market: the RBV}

The use of market information has been an issue of great interest in recent years (for example, Jones and Suh, 2000; Souchon and Diamantopoulos, 1996). There is a growing realization of the importance of the use of market information (Brown and Dev, 2000), and it is now accepted that market information is crucial for a firm's success or failure (Brown and Dev, 2000; Jones and Suh, 2000; Souchon and Diamantopoulos, 1996). Firms operating in international markets and in unfamiliar export environments are exposed to additional uncertainty (McAuley, 1993), and the importance of information as a key factor influencing a firm's export behavior has long been acknowledged in the international marketing literature (Diamantopoulos, 2003). Previous studies have shown that the strongest motivations for exporting are of economic character (Burpitt and Rondinelli, 2000), which to a large degree is mirrored in the operationalization of the performance construct in export-related studies (Katsikeas et al., 2000). Export firms use export information to overcome decision-making uncertainty caused by the potentially unfamiliar environment, and this information acts as a key determinant for entry and expansion decisions and is an essential prerequisite to making successful business decisions (Ajayi, 2003). In fact, use of information has frequently been seen as a critical determinant to export performance (Diamantopoulos et al., 2003). Also, the desire to acquire new knowledge and new skills has been shown to be of great importance for exporting (Burpitt and Rondinelli, 2000).

Knowledge includes interpretation (Huber, 1991), understanding (Bierly et al., 2000), commitment (Nonaka, 1994) and creation of new knowledge (Takeuchi, 2001), and using information, i.e. incorporating and integrating it into the organisation is one way of increasing organisational knowledge (Probst et al., 1998). It has further been proposed that knowledge can directly influence a firm's performance (Seringhaus, 1991; Toften and Olsen, 2003). Aaby and Slater (1989) empirically stated that market knowledge becomes a strong influence for any successful exporters. Brencic, Ekar and Virant (2008) described that knowledge about the market influences firm's export performance based on the internalization theory. Again, those authors used a model from the Uppsala School, which was proposed by Johanson and 
Vahlne in 1977, who found that experiential knowledge is a part of market knowledge and strongly influences performance. Meanwhile, Boughanmi, Al-Mandheri and Omezzine (2007) mentioned that the education level and previous work experience reflects the management skill and knowledge in international business thereby influencing export performance. However, several problems and shortcomings become evident in the literature. First, export knowledge, despite its stated importance (Burpitt and Rondinelli, 2000; Seringhaus, 1991; Toften and Olsen, 2003), appears to be few in the empirical studies. Secondly, empirical findings concerning relations between use of export market information, export knowledge and export performance are scarce, even though there seems to be agreement that such relationships exist (Hart and Tzokas, 1999; Seringhaus, 1991; Souchon and Diamantopoulos, 1999; Toften and Olsen, 2003). Further, use of export market information in terms of its dimensions has not been tested on outcome variables such as knowledge and performance (Toften, 2005).

\section{Export Marketing Strategy: Perspectives from Contingency, Market Imperfections and Industrial Organization Theories}

In today's competitive global marketplace, the importance of formulating an effective marketing strategy has been receiving increased attention. The relationship between export marketing strategy and performance has received considerable attention in the literature (Christensen et al., 1987; Koh and Robicheaux, 1988; Miesenbock, 1988; Ford and Leonidou, 1991; Cavusgil and Zou, 1994; Da Rocha and Christensen, 1994). However, most studies have considered specific marketing strategy elements in isolation or have explored the relationship between marketing strategy and performance relationship in the context of a developed country. As such, most empirical examinations of the relationship have been derived from narrow strategy orientations of exporters in developed countries, and have not addressed the marketing issues of exporters in developing economies (Dominguez and Brenes, 1997). Given the differences between developed and developing economies, the generalization of prior research to exporters in a developing economy context may not be appropriate (Aulakh et al., 2000). The lack of research in this area is a limitation in the literature (Lee \& Griffith, 2004).

Moreover, among the determinants proposed to influence export performance, factors related to the firm's export marketing strategy have been the most frequently cited antecedents in the literature. It has been argued that strategy results from matching a firm's skills and resources, environmental opportunities and managerial preferences; then structure and strategy affect performance (Rumelt 1986). The underlying premise is that a firm's performance is determined primarily by two fundamental sets of antecedents (Morgan et al. 2004). First are the structural characteristics of the firm's markets that determine the competitive intensity the firm faces. Second is the firm's capability to achieve and sustain positional advantages through the efficient execution of planned competitive strategy. Thus, a large number of studies have explored the importance of export marketing strategy on export performance, particularly the extent to which the elements of the marketing program (product, price, promotion and distribution) are standardized or adapted across markets. As with most determinants of export performance, the results have been inconsistent and often 
contradictory. An explanation could be that what leads to superior performance is not the adoption of marketing strategy standardization or adaptation per se but the achievement of an appropriate 'fit' between strategy and its context whether it is the external environment or organizational characteristics (Cavusgil and Zou 1994). This appears to be consistent with the findings of O'Cass and Julian (2003) that the extent of adaptation of the marketing mix variables (product, price, promotion and distribution) was not significantly associated with export performance. They argue that, depending on the industries, some firms (eg chemical industries) could achieve better performance by pursuing a standardization strategy, whereas other industries (eg metalworking industries) could achieve better results following an adaptation strategy. The view that no strategy can be effective in all contexts is also a fundamental premise of the contingency theory. This theory holds that export success depends on the context in which a firm is operating and that effectiveness depends on the appropriate matching of organizational contingency factors to fit the firm's context (Zeithaml et al. 1985).

\subsection{Strategic Orientation}

The strategic orientation of the firm has also been identified as influencing the performance of the firm. In the literature, several authors (eg Francis and Collins-Dodd 2000; Lado et al. 2004) use the categorization of proactive/ reactive to discern the strategic orientation of the firm. Proactiveness hinges on the firm taking the initiative in venturing out to seek opportunities and in investigating alternative responses to a changing environment. It seems, therefore, logical that, in an exporting context, a proactive orientation is positively associated with the export performance of the firm. Contrary to reactively motivated firms, proactive firms are more aware of internal and external conditions, thereby exhibiting informational advantages that might lead to higher performance levels (Lee and Yang 1990).

\subsection{Marketing Research}

Another determinant in this sub-category that should not be overlooked is marketing research. Several empirical studies have mentioned that marketing research is an important element in the firm's foreign success (eg Hart and Tzokas 1999; Ling-yee 2004; Yeoh, 2000). Knowledge, and its acquisition and exploitation, has been declared as the key resource to create sustainable competitive advantages (Nahapiet and Ghoshal 1998; Tsai and Ghoshal 1998). In the new era of global competition, it is asserted that firms succeed not because they have superior control over scarce resources (Inkpen 1998), but because they are able to learn and to use this learning more efficiently than others (Larsson et al. 1998). Given the complexity and uncertainty surrounding export decisions, information acquisition is viewed as a primary means of minimizing the likelihood of negative consequences in the international marketplace (Cavusgil 1980; Souchon and Diamantopoulos 1997; Walters and Samiee 1990).Co-operative strategy and marketing process were used only by Haahti et al. (2005) and Chung (2003), respectively. Both variables, however, were found to have a non-significant effect on the export performance of the firm.

Co-operative strategy refers to the level of co-operation that exists with other firms, and the results indicate that there is no direct relationship between this variable and export 
performance. The reason appears to be that the primary purpose of pursuing a co-operative strategy is not to improve the export performance directly, but to increase the firm's knowledge acquisition (Haahti et al. 2005). Research regarding marketing process and its relationship with export performance has been scarce in the literature. Nevertheless, previous studies have shown that standardization of the process is likely to affect the firm's performance (Kotabe 1990; Walters 1986). The results provided by Chung (2003), however, indicate that the degree of standardization of marketing processes has no significant effect on export performance. This means that research on the impact of process strategy on the export performance of the firm is far from definite.

The lack of studies in the literature that have examined this relationship and the contradictory findings of those that have addressed it should encourage researchers to incorporate this variable into their further studies. The distribution channel relationship was analyzed only by Styles and Ambler (2000) and Ling-yee and Ogunmokun (2001b). Both studies provide evidence that relational variables such as the distribution channel relationship have a positive impact on the export performance of the firm. However, having only two studies that examine the distribution channel relationship appears to corroborate the view of Morgan and Hunt (1999) that research into the strategic implications of relationship marketing has been largely neglected. Relationship marketing involves the creation of strong, long-term relationships with selected customers, suppliers or other value-chain partners of a firm, and is based on two axioms: mutual cooperation and mutual interdependence (Sheth and Parvatiyar 1995). The importance of including relational variables in future research studies becomes apparent when considering that the development of mutually beneficial, trust-based relationships with foreign partners can be viewed as a source of enduring advantage, particularly in the contemporary global business environment, where classical marketing tools such as price and product quality are susceptible to imitation by rivals (Zhang et al. 2003).

Export Marketing Strategy as part of Strategic Management Exporting can be conceptualized as a strategic response by management to the interplay of internal and external forces. As such, the strategy and performance of export marketing can be analyzed within the general framework of strategic management. In this framework, the strategies of cost leadership and differentiation define how a firm develops an advantage with respect to competitors in an industry (Porter, 1980, 1986). As firms begin to compete in export markets, their export success depends upon their ability to develop and implement unique competitive strategies. When developing strategies of cost leadership and/or differentiation, these firms have to match their internal and location specific competitive and comparative advantages with the requirements of the external environment in which they compete (Aulakh, Kotabe and Teegen, 2000). Firms following a differentiation strategy aim at creating a product or service that customers see as unique. This is usually accomplished through such means as a superior brand image, technology, customer service or innovative products (Miller, 1988). A cost-leadership strategy involves giving consumers value comparable to that of other products at a lower cost (Porter, 1986). This strategy can provide above average returns because firms following cost leadership can lower prices to match those of competitors and 
still earn profits (Miller, 1988).

\section{Determinants of Export Market Performance in the Ghanaian Wood Industry}

Ghana's deforestation rate is presently estimated at approximately 65,000 ha per year. Much forestland outside the forest reserves (in the so-called off-reserve areas) has been degraded and converted to farmland over the past decades. The current off-reserve forest areas consist of a mosaic of agricultural fields, mostly cocoa and food crop farms, fallow lands, secondary forest patches and trees around settlements (Mayers et al. 1996; Kotey et al. 1998). About 350,000 ha of off-reserve areas are currently available for timber production (Affum-Baffoe 2010). Management is part of the internal environment and includes the ability to use appropriate technology, establish and nurture committed personnel, acquire knowledge, set export aims, and establish management control systems. The rationale for this view is that, when managers are committed, they carefully plan the entry and allocate sufficient managerial and financial resources (Cavusgil and Zou 1994; O'Cass and Julian 2003). The lack of studies in the literature that have examined this relationship and the contradictory findings of those that have addressed it should encourage researchers to incorporate this variable into their further studies. The main forest regulations applied in Ghana involved the application of minimum felling diameters, felling cycle lengths, and a selected number of stems for allowable cut (selective logging). Application of felling diameter limits forty year felling cycle was introduced (Boakye-Dapaah 1990; Asamoah-Adam et al. 2006). Exporters of value added wood products using the primary timber species were entitled to a refund of $1 \%$ of the F.O.B value whilst those using the lesser used timber species were entitled to $2 \%$.

\section{Conclusions and Recommendations}

Research appears to indicate that the existence of programs sponsored by government and nongovernment agencies designed to assist firms' export activities contribute positively to the export performance of the firm. The presence of a research and development (R\&D) function within a firm, may stimulate innovation through the type of technology push process envisaged in linear models of innovation. The ability to analyze and plan is a discriminator between successful exporters and non-exporters and poor management causes weak performance. Managerial Competence Exporting is a dynamic process and managers need to monitor environmental changes and be proactive and flexible in making strategy. Export success is linked to effective control and monitoring of performance, decentralized decision making, and education and training. In providing tangible products like wood, some amount of services will be necessary to enhance the marketability of the product. This can eventually affect the performance of the industry in the sense that when services are attached to the delivering of wood products, the customer perceives it as attaining superior value which results in increase performance. The importance of the wood industry to the growth of Ghana's GDP cannot be overemphasized. Thus, policy makers have always sought the best mix of policies that will enhance the performance of the industry and thus its contribution to economic growth. 


\section{Reference}

Aaby, N. E., \& Slater, S. F. (1989). Managerial influences on export performance: a review of the empirical literature 1978-88, International Marketing Review, 6(4), 53-68.

Affum-Baffoe, K. (2010). Global Forest Resources Assessment 2010. Country Report, Ghana. FRA 2010/077. Rome, 49.

Alvarez, R. (2004). Sources of export-success in small and medium sized enterprises: the impact of public programs, International Business Review, 13, 383-400.

https://doi.org/10.1016/j.ibusrev.2004.01.002

Anderson, E. W., \& Sullivan, M. W. (2005). The antecedents and consequences of customer satisfaction for firms. Marketing Science, 12(2), 125-143.

https://doi.org/10.1287/mksc.12.2.125

Barrett, N. I., \& Wilkinson, I. F. (1985). Export stimulation: a segmentation study of the exporting problems of Australian manufacturing firms, European Journal of Marketing, 19(2), 53-72. https://doi.org/10.1108/EUM0000000004750

Brown, J. R., \& Dev, C. S. (2000). Improving productivity in a service business. Journal of Service Research, 2(4), 339-354. https://doi.org/10.1177/109467050024003

Burton, F. N., \& Schlegelmilch, B. B. (1987). Profile analysis of non-exporters versus exporters grouped by export involvement, Management International Review, 27(1), 38-49.

Cavusgil, S. T. (1984). Firm and management characteristics as discriminators of export marketing activity, Journal of Business Research, 15(3), 221-35.

https://doi.org/10.1016/0148-2963(87)90025-7

Cavusgil, S. T., \& Zou, S. (1994). Marketing strategy-performance relationship: an investigation of the empirical link in export market ventures, Journal of Marketing, 56, 1-21. https://doi.org/10.2307/1252247

Chetty, S. K., \& Hamilton, R. T. (1993). Firm-level determinants of export performance: a metaanalysis, International Marketing Review, 10(3), 26-34.

https://doi.org/10.1108/02651339310040643

Christensen, C. H., da Rocha, A., \& Gertner, R. K. (1987). An empirical investigation of the factors influencing exporting success of Brazilian firms, Journal of International Business Studies, 18(3), 61-77. https://doi.org/10.1057/palgrave.jibs.8490412

Dau, R. (1992). Marketing orientation and export performance in the New Zealand manufacturing industry, unpublished PhD dissertation, Victoria University of Wellington.

Diamantopoulos, A., \& Cadogan, J. (1996). Internationalising the market orientation construct: an in-depth interview approach, Journal of Strategic Marketing, 4, 23-52. https://doi.org/10.1080/09652549600000002

Evangelista, F. U. (1994). Export performance and its determinants: some empirical evidence 


\section{Macrothink Institute $^{\mathrm{TM}}$}

from Australian manufacturing firms, in Cavusgil, S.T. and Axinn, C. (Eds), Advances in International Marketing, JAI Press, Greenwich, CT, 6, 207-29.

Ford, I., \& Leonidou, L. (1991). Research developments in international marketing, in Paliwoda, S. (Ed.), New Perspectives on International Marketing, Routledge, London, 3-32.

Ghana Statistical Service (2011). Provisional GDP Estimates and Sector Performance Report.

Jones, M. A., \& Suh, J. (2000). Transaction-specific satisfaction and overall satisfaction: an empirical analysis. Journal of Services Marketing, 14, 147-159.

https://doi.org/10.1108/08876040010371555

Katsikeas, C. S., Piercy, N. F., \& Ioannidis, C. (1996). Determinants of export performance in a European context, European Journal of Marketing, 30(6), 6-35.

https://doi.org/10.1108/03090569610121656

Katsikeas, C. S., Leonidou, L. C., \& Morgan, N. A. (2000). Firm-level export performance assessment: review, evaluation, and development, Journal of the Academy of Marketing Science, 28(4), 493-511. https://doi.org/10.1177/0092070300284003

Leonidou, L. C., Katsikeas, C. S., \& Samiee, S. (2002). Marketing strategy determinants of export performance: a meta-analysis, Journal of Business Research, 55(1), 51-67.

https://doi.org/10.1016/S0148-2963(00)00133-8

Madsen, T. K. (1989). Successful export marketing management: some empirical evidence, International Marketing Management, 6(4), 41-57.

https://doi.org/10.1108/eum0000000001518

Maurel, C. (2009). Determinants of Export Performance in French Wine SMEs. International Journal of Wine Business Research, 21(2), 118-142.

https://doi.org/10.1108/17511060910967971

McGuinness, N. W., \& Little, B. (1981). The influence of product characteristics on the export performance of new industrial products, Journal of Marketing, 45, 110-22. https://doi.org/10.2307/1251670

Moini, A. H. (1995). An inquiry into successful exporting: an empirical investigation using a three-stage model, Journal of Small Business Management, 33, 9-25.

Sasatani, D. (2009). National competitiveness index of the forest products industry in the Asia Pacific Region: Asia-Pacific Forestry Sector outlook study II, Working Paper No. APFSOS II/WP/2009/25

Shoham, A. (1996). Marketing-mix standardization: determinants of export performance, Journal of Global Marketing, 10(2), 53-73. https://doi.org/10.1300/J042v10n02_04

Slater, S. F., \& Narver, J. C. (1996). Competitive strategy in the market focused business, Journal of Market-Focused Management, 1, 159-74. https://doi.org/10.1007/BF00128688

Sousa, C. M. P. (2004). Export performance measurement: an evaluation of the empirical 
research in the literature, Academy of Marketing Research, 9, 1-22.

Wilkinson, T., \& Brouthers, L. E. (2006). Trade promotion and SME export performance, International Business Review, 15(3), 233-52. https://doi.org/10.1016/j.ibusrev.2006.03.001

Zeithaml, V. A., Parasuraman, A., \& Berry, L. L. (1985). Problems and strategies in services marketing, Journal of Marketing, 49, 33-46. https://doi.org/10.2307/1251563

\section{Copyright Disclaimer}

Copyright for this article is retained by the author(s), with first publication rights granted to the journal.

This is an open-access article distributed under the terms and conditions of the Creative Commons Attribution license (http://creativecommons.org/licenses/by/3.0/). 